\title{
TAMAN DAN PERANANNYA TERHADAP AKTIVITAS BERJALAN KAKI DI KOTA YOGYAKARTA
}

\author{
Lucia Vina Wulandari \\ Magister Perencanaan Wilayah dan Kota, Departemen Teknik Arsitektur dan Perencanaan, \\ Universitas Gadjah Mada \\ email: luviland09@gmail.com
}

\begin{abstract}
ABSTRAK
Taman sering digunakan pada upaya peningkatan aktivitas berjalan kaki karena keduanya berkaitan dengan aktivitas fisik dan bersifat ramah lingkungan. Dewasa ini, aktivitas berjalan kaki semakin perlu dikembangkan untuk mewujudkan kota yang berkelanjutan. Studi ini membahas mengenai taman dan peranannya terhadap aktivitas berjalan kaki melalui metode penyebaran kuisioner kepada pengunjung taman rekreasional di Kota Yogyakarta dan observasi lapangan. Selanjutnya data yang diperoleh dianalisis menggunakan metode statistik. Hasil studi menunjukkan bahwa meskipun taman dijadikan sebagai ruang untuk beraktivitas fisik, namun hanya $14.6 \%$ dari total responden yang memiliki preferensi berjalan kaki untuk pergi menuju ke taman. Berjalan kaki yang merupakan salah satu aktivitas fisik tidak banyak dipilih pengunjung taman sebagai moda transportasi menuju ke taman. Jarak tempuh dan durasi menuju ke taman menjadi salah satu faktor yang berkaitan dengan preferensi berjalan kaki. Semakin jauh jarak yang ditempuh responden maka akan semakin kecil preferensi berjalan kaki yang dimiliki oleh responden. Mereka akan cenderung untuk tidak memilih berjalan kaki sebagai moda transportasi yang digunakan untuk menuju ke taman. Selain itu, jarak dan durasi tempuh juga memiliki hubungan dengan intensitas kunjungan ke taman. Jarak tempuh yang jauh akan mengurangi intensitas kunjungan ke taman. Hasil lainnya, tinggi rendahnya intensitas kunjungan ke taman akan berdampak pada tinggi rendahnya frekuensi berjalan kaki. Sehingga berdasarkan hasil tersebut, keberadaan taman dapat memberikan dampak pada aktivitas berjalan kaki di Kota Yogyakarta.

Kata kunci: Berjalan kaki, Pedestrian, Taman, Transportasi-aktif
\end{abstract}

\section{PARKS AND ITS ROLE ON THE WALKING ACTIVITY IN YOGYAKARTA CITY}

\begin{abstract}
Parks are often used to promote walking activity, especially in urban area, because both of them are related to physical activities and also eco-friendly. This study discusses parks and their roles in walking activities by questionnaires distribution to the recreational park visitors in Yogyakarta City and through field observations. Furthermore, the data obtained were analyzed using statistical methods. The results of the study show that although the park is used as a space for physical activity, only $14.6 \%$ of the total respondents prefer walking to the park. Walking, as a physical activity, is not favorable to be chosen by park visitors as a transportation-mode to the park. The distance and duration to the park are factors related to walking preferences. The farther the distance traveled by the respondents, the lower the respondent's walking preference. They will not to choose walking as the transportation-mode used to go to the park. In addition, the trip distance and duration also have a relationship with the intensity of visits to the park. The intensity to visit the park will be reduced if people passed a long route. Another result, the intensity of visits to the park will have an impact on walking frequency. So based on these results, the existence of parks can enhance the walking activities in the Yogyakarta city..

Keywords: Walking, Pedestrian, Park, Active-transportation
\end{abstract}

\section{PENDAHULUAN}

Peningkatan moda transportasi aktif seperti berjalan kaki menjadi salah satu strategi penting untuk mengatasi permasalahan yang dihadapi di wilayah perkotaan seperti ketergantungan yang tinggi terhadap kendaraan bermotor pribadi, permasalahan lingkungan dan juga kesehatan (Song Yena, Preston John, Ogilvie David, 2017). Dalam Reisi,dkk, 2019 disebutkan bahwa berjalan kaki merupakan salah satu bentuk aktivitas fisik yang populer (Bahrainy et al., 2015) dan membuat para perencana kota tertarik pada aktivitas ini dalam hal pengurangan emisi gas (Tribby et al., 2016).

Menurut Schmid (2006), dalam Cambra (2012), berjalan kaki pada dasarnya dibedakan menjadi dua jenis yaitu berjalan kaki sebagai fungsi transportasi yaitu berjalan kaki untuk mencapai suatu tujuan/tempat seperti berjalan kaki menuju ke tempat perbelanjaan, atau sekolah atau tempat kerja, dan berjalan kaki sebagai fungsi aktivitas rekreasional yang berkaitan dengan aktivitas fisik seperti berolahraga. Lebih lanjut, dalam tulisan Adriana A., dkk. (2017), disebutkan bahwa lingkungan 
terbangun (built environment) memberikan efek yang berbeda bagi masing-masing jenis aktivitas berjalan kaki. Berjalan kaki sebagai fungsi transportasi menunjukkan adanya hubungan dengan desain dari lingkungan sekitarnya. Hal ini berbeda dengan karakteristik dari berjalan kaki sebagai fungsi rekreasional yang tidak menunjukkan adanya kaitan dengan desain dari lingkungan sekitarnya (Saelens et al., 2003).

Banyak teori yang menyebutkan bahwa aktivitas berjalan kaki dipengaruhi oleh beberapa faktor. Seperti misalnya dalam Reisi, dkk., 2019, disebutkan bahwa aktivitas berjalan kaki dipengaruhi oleh perilaku berjalan kaki, kenyamanan, konektivitas, aksesibilitas, keamanan, kemenarikan dan keindahan.

Menurut Peraturan Menteri Pekerjaan Umum No. 03 / PRT / M / 2014 dalam lampiran, ada 4 faktor yang mempengaruhi jarak tempuh orang berjalan kaki. Faktor pertama adalah motif yang berkaitan dengan seberapa kuat motif orang ketika berjalan menempuh suatu tujuan. Sebagai contoh, seorang pejalan kaki yang memiliki motif untuk berbelanja sanggup berjalan kaki selama dua (2) jam atau jarak sekitar dua koma lima (2.5) Kilometer tanpa disadarinya. Sementara motif untuk rekreasi menempuh jarak yang lebih pendek daripada berbelanja. Faktor kedua adalah kenyamanan. Cuaca dan tipe aktivitas mempengaruhi faktor ini. Seperti misalnya cuaca panas membuat orang kurang nyaman untuk berjalan jauh. Semakin nyaman aktivitas yang dilakukan, semakin jauh jarak yang dapat ditempuh pejalan kaki. Faktor ketiga adalah ketersediaan moda transportasi umum yang memadai akan mendorong orang untuk berjalan kaki lebih jauh. Keberadaan penempatan fasilitas publik yang memadai akan mendorong orang untuk berjalan kaki lebih jauh dibandingkan apabila ketersediaan fasilitas yang tidak merata. Faktor keempat adalah pola guna lahan dan kegiatan. Pola guna lahan campuran (mixed land-used) yang beragam akan menghasilkan jarak tempuh berjalan kaki yang lebih jauh dibandingkan tata guna lahan homogen. Di kawasan pusat perbelanjaan, sampai dengan jarak 500 meter akan terasa menyenangkan. Lebih dari jarak itu diperlukan spot fasilitas untuk mengurangi kelelahan seperti tempat duduk atau kios yang menyediakan makanan/minuman.

Warpani (1990) dalam Nasution, N., Widiyastuti, D., \& Purwohandoyo, J. (2018) menyebutkan bahwa tujuan dan jarak perjalanan mempengaruhi pemilihan moda transportasi. Tujuan perjalanan menunjuk pada lokasi yang ingin dicapai. Sedangkan jarak mengacu pada panjang lintasan yang dilalui. Pada umumnya, semakin pendek jarak yang ditempuh, orang cenderung untuk memilih moda transportasi yang sederhana termasuk di dalamnya adalah moda transportasi berjalan kaki

Sedangkan Saelens, dkk. (2003) menyebutkan bahwa keputusan untuk memilih menggunakan moda transportasi bermotor atau tidak bermotor dipengaruhi oleh beberapa faktor yaitu jarak dan konektivitas (kemenerusan dalam perjalanan). Selain itu biaya perjalanan, kenyamanan, kualitas lingkungan dan aksesibilitas juga memberikan pengaruh terhadap pengambilan keputusan.

Sebagaimana disebutkan dalam National Recreation and Park Association (2015) moda transportasi aktif seperti berjalan kaki sering dikaitkan dengan taman. Sebagai ruang terbuka hijau, taman memiliki kesamaan sifat dengan moda transportasi aktif yaitu ramah lingkungan dan berkaitan dengan aktivitas fisik. Untuk itu taman seringkali dijadikan sebagai salah satu sarana untuk meningkatkan preferensi pemilihan moda transportasi aktif. Menurut Çay, R. D. (2015), sebagai ruang public, taman kota harus dibuat menarik bagi semua kelompok usia. Perencanaannya dikaitkan dengan hal-hal yang dapat mendorong peningkatan aktivitas fisik dalam bentuk fasilitas rekreasi dan semua kelompok usia memiliki kesempatan untuk menikmatinya.

Berdasarkan tipe aktivitasnya, Wibowo dan Ritonga (2018) menyatakan bahwa taman kota dibagi menjadi dua tipe yaitu taman aktif yang diartikan sebagai taman yang fasilitasnya dapat dimanfaatkan /digunakan oleh pengunjung, dan pengunjung dapat melakukan aktivitas yang sifatnya rekreasional di taman tersebut seperti berolah raga, relaxasi, bermain atau sekedar duduk/berjalan-jalan menikmati keadaan sekeliling taman. Sedangkan tipe taman kedua adalah taman pasif yaitu taman yang memiliki fungsi sebagai penyeimbang lingkungan dan tidak memiliki fasilitas yang dapat dimanfaatkan oleh pengunjung.

Sebagaimana disebutkan oleh Dills James E., Rutt Candace D. , \& Mumford Karen G. (2012), beberapa penelitian menunjukkan bahwa faktor lingkungan baik itu lingkungan sekitar maupun tamantaman memberikan pengaruh pada aktivitas fisik seperti berjalan kaki. Lebih lanjut, dalam penelitian Duncan T. Dustin (2016), hasil studi menunjukkan bahwa aktivitas berjalan kaki di paris berhubungan erat dengan lingkungan yang walkable. Kondisi walkable tersebut juga dapat menjadi strategi yang relevan untuk meningkatkan kesehatan melalui aktivitas fisik.

Sebagai ibukota dari Provinsi Daerah Istimewa Yogyakarta, Kota Yogyakarta memiliki kepadatan penduduk yang lebih tinggi daripada kabupaten lain di wilayah Provinsi DIY. Jumlah penduduk dari tahun ke tahun pun semakin meningkat. Di tahun 2019 jumlah penduduk kota Yogyakarta meningkat 
4.66\% dibandingkan tahun 2015 (Badan Pusat Statistik, 2016;2020). Pertambahan jumlah penduduk tersebut juga diikuti dengan meningkatnya jumlah kendaraan bermotor sebesar $20 \%$ di tahun 2019 bila dibandingkan tahun 2015 (Badan Pusat Statistik, 2020). Hal tersebut dapat memicu terjadinya permasalahan kota seperti kemacetan lalu lintas dan penurunan kualitas lingkungan di Kota Yogyakarta. Untuk mengatasi permasalahan tersebut, Pemerintah Kota Yogyakarta sejak beberapa tahun terakhir melakukan berbagai upaya melalui beberapa kegiatan seperti penambahan jumlah ruang terbuka hijau baik berupa taman aktif, pasif maupun jalur hijau, dan pengembangan jalur pedestrian di beberapa titik. Menurut Dokumen Rencana Pembangunan Jangka Menengah Daerah (RPJMD) 2017-2022 Kota Yogyakarta, taman sebagai ruang terbuka hijau selain memiliki fungsi untuk menyerap emisi yang dihasilkan penduduk kota dan menurunkan iklim mikro juga menambah nilai estetika kota. Selain itu, pengembangan jalur pedestrian sebagai salah satu langkah yang mengarah pada transportasi yang berkelanjutan ditujukan untuk mengurangi kemacetan lalu lintas yang berdampak pada menurunnya kualitas lingkungan dan kualitas hidup sehat di Kota Yogyakarta. Dalam hal ini peneliti melihat pentingnya keberadaan taman dan aktivitas berjalan kaki dalam mengatasi permasalahan di kota Yogyakarta.

Berdasarkan hal tersebut peneliti ingin mengetahui apakah taman yang erat kaitannya dengan aktivitas fisik memiliki peranan terhadap aktivitas berjalan kaki. Bagaimana tingkat preferensi berjalan kaki dari pengunjung taman untuk berjalan kaki menuju taman? Dan bagaimanakah karakterisik dari pengunjung taman yang terkait dengan aktivitas berjalan kaki? Dalam studi ini peneliti menjadikan taman rekreasional sebagai salah satu obyek penelitian dikarenakan taman merupakan titik potensial yang berkaitan erat dengan aktivitas fisik seperti berjalan kaki.

Penulis berharap studi ini dapat menjadi langkah awal untuk memahami karakteristik pengunjung taman yang berkaitan dengan aktivitas berjalan kaki. Tujuan dari studi ini adalah untuk menyajikan hasil penelitian mengenai preferensi aktivitas berjalan kaki dari pengunjung taman rekreasional khususnya yang berada di Kota Yogyakarta. Preferensi yang dimaksudkan disini adalah kecenderungan pilihan dari seseorang untuk memilih sesuatu hal yang lebih disukainya. Diharapkan, informasi yang diperoleh mengenai perilaku dan minat untuk berjalan kaki serta persepsi dari pengunjung taman terhadap kondisi eksisting jalur pedestrian dapat memberikan input dalam perencanaan pengembangan jalur pejalan kaki di Kota Yogyakarta.

\section{METODE PENELITIAN}

Studi ini terdiri dari dua tahapan. Tahap pertama adalah pengumpulan data primer dan data sekunder. Data primer diperoleh melalui penyebaran kuisioner yang dilakukan pada rentang waktu Agustus - Desember 2019, sedangkan data sekunder didapatkan melalui studi literatur menggunakan jurnal, artikel-artikel, laporan-laporan maupun data institusional.

Dalam mengumpulkan data primer, kuisioner didistribusikan kepada dua ratus sembilan puluh empat (294) orang pengunjung taman rekreasional di Kota Yogyakarta yang dipilih secara random melalui teknik accidental sampling yaitu teknik pengambilan sample penelitian berdasarkan kebetulan. Maksudnya adalah siapa saja yang berkunjung ke taman yang dijadikan obyek dalam penelitian ini dan secara kebetulan bertemu dengan peneliti dan dipandang cocok sebagai sumber data dapat dijadikan sampel penelitian (Sugiyono, 2009). Teknik accidental tersebut dipilih dalam penelitian ini karena tidak adanya populasi yang khusus terkait pengunjung taman rekreasional tersebut. Taman-taman dalam studi ini bersifat terbuka, pengunjung bebas untuk keluar masuk dan tidak ada sumber yang dapat menginformasikan secara resmi mengenai jumlah pengunjung taman baik itu dalam kurun waktu sehari maupun kurun waktu yang lebih lama seperti sebulan atau setahun.

Kuisioner sebagai instrumen asesmen terdiri dari pertanyaan yang sifatnya tertutup (close-ended) dan terbuka (open-ended). Kuisioner tersebut menggali informasi dari responden mengenai profil responden seperti usia, jenis kelamin, pekerjaan, alamat, dan kepemilikan kendaraan. Pada bagian kedua, pertanyaan yang diberikan kepada partisipan adalah yang terkait dengan karakteristik kunjungan ke taman dan perjalanan yang ditempuh menuju ke taman seperti tujuan kunjungan, intensitas kunjungan ke taman, serta jarak dan durasi yang ditempuh untuk menuju ke taman. Bagian selanjutnya adalah preferensi aktivitas berjalan dari para pengunjung taman seperti pilihan moda transportasi yang digunakan untuk pergi ke taman, alasan pemilihan moda transportasi yang digunakan, ketersediaan jalur

\section{3| Taman dan Peranannya terhadap Aktivitas Berjalan Kaki Di Kota Yogyakarta}


pejalan kaki, ketersediaan jalur penyeberangan, dan aspek yang harus diperbaiki berdasarkan perspektif responden. Selain itu peneliti juga menggali perilaku berjalan kaki dalam keseharian responden seperti intensitas aktivitas berjalan kaki yang dilakukan dalam kesehariannya yang menggambarkan seberapa sering responden tersebut melakukan aktivitas berjalan kaki.

Selanjutnya tahap kedua adalah pengolahan data. Menggunakan hasil assessment dari kuisioner yang telah diisi oleh para responden, peneliti melakukan pengolahan data secara statistical menggunakan analisis deskriptif dan analisis korelasi dan regresi dengan menggunakan software SPSS. Analisis korelasi digunakan untuk menguji ada atau tidaknya hubungan antara dua variable atau lebih. Sedangkan analisis regresi digunakan untuk menguji adanya pengaruh antara variable bebas (independent) terhadap variable tergantung (dependent) (Sujarweni V. Wiratna, 2019). Dalam penelitian ini, analisis korelasi digunakan untuk untuk menguji apakah ada hubungan yang signifikan antara jarak dan durasi tempuh terhadap intensitas kunjungan ke taman dan terhadap preferensi berjalan kaki. Serta menguji apakah ada hubungan yang signifikan antara intensitas kunjungan ke taman dengan intensitas berjalan kaki dari responden.

Untuk menghindari terjadinya penyimpangan atau pelebaran subjek dan pembahasan studi, maka ruang lingkup penelitian ini dibatasi oleh lokasi dan focus penelitian. Beberapa keterbatasan dalam penelitian ini yaitu lokasi penelitian adalah Kota Yogyakarta, dengan focus studi yaitu preferensi pengunjung taman rekreasi aktif di Kota Yogyakarta dalam hal aktivitas berjalan kaki

Area dalam studi ini adalah sembilan taman rekreasional yang memiliki karakteristik sejenis yaitu berupa ruang terbuka hijau di area Kota Yogyakarta, yang bisa digunakan sebagai ruang untuk melakukan aktivitas rekreasional seperti olahraga, bermain atau bersantai dan bebas diakses oleh masyarakat. Selain itu, taman dalam studi ini berada di jalan utama yang mudah diakses dan memiliki potensi untuk dikembangkan jalur pedestriannya. Mayoritas berupa lapangan olahraga atau alun-alun kota. Namun ada satu taman yang memiliki fungsi utama sebagai reservoir / embung. Tetapi meskipun begitu, embung ini juga dilengkapi dengan sarana rekreasional seperti jogging track atau area untuk berolahraga. Kesembilan taman rekreasional dalam studi ini yaitu: Lapangan Minggiran, Lapangan Karang, Stadion Kridosono, Stadion Mandala Krida , Lapangan Sidokabul, Alun-alun Utara, Alun-alun Selatan, Pakualaman dan Embung Langensari, sebagaimana ditampilkan pada tabel 1. Berikut

Tabel 1. Taman rekreasional dan tipe taman

\begin{tabular}{llll}
\hline No & Taman & Lokasi & Tipe/fasilitas \\
\hline $\mathbf{1}$ & Embung Langensari & $\begin{array}{l}\text { Kecamatan } \\
\text { Gondokusuman }\end{array}$ & $\begin{array}{l}\text { Kolam reservoir, jogging track dan ruang terbuka } \\
\text { hijau }\end{array}$ \\
\hline $\mathbf{2}$ & Stadion Kridosono & $\begin{array}{l}\text { Kecamatan } \\
\text { Gondokusuman }\end{array}$ & $\begin{array}{l}\text { Ruang terbuka hijau berupa stadion olah raga } \\
\text { yang dilengkapi dengan spot kuliner }\end{array}$ \\
\hline $\mathbf{3}$ & Alun-alun utara & $\begin{array}{l}\text { Kecamatan } \\
\text { Gondomanan }\end{array}$ & $\begin{array}{l}\text { Alun-alun kota yang dikelilingi oleh pedagang } \\
\text { kaki lima }\end{array}$ \\
\hline $\mathbf{4}$ & Alun-alun selatan & Kecamatan Kraton & $\begin{array}{l}\text { Alun-alun kota yang dikelilingi oleh pedagang } \\
\text { kaki lima }\end{array}$ \\
\hline $\mathbf{5}$ & $\begin{array}{l}\text { Lapangan } \\
\text { Minggiran }\end{array}$ & Kecamatan Mantrijeron & $\begin{array}{l}\text { Lapangan olehraga dengan beberapa pedagang } \\
\text { kaki lima yang berjualan makanan }\end{array}$ \\
\hline $\mathbf{6}$ & $\begin{array}{l}\text { Lapangan } \\
\text { Sidokabul }\end{array}$ & Kecamatan Umbulharjo & $\begin{array}{l}\text { Lapangan oleh raga dengan beberapa pedagang } \\
\text { kaki lima yang berjualan makanan }\end{array}$ \\
\hline $\mathbf{7}$ & $\begin{array}{l}\text { Lapangan Karang } \\
\text { Kotagede }\end{array}$ & Kecamatan Kotagede & $\begin{array}{l}\text { Lapangan oleh raga dengan beberapa pedagang } \\
\text { kaki lima yang berjualan makanan }\end{array}$ \\
\hline $\mathbf{8}$ & Pakualaman & $\begin{array}{l}\text { Kecamatan } \\
\text { Pakualaman }\end{array}$ & $\begin{array}{l}\text { Alun-alun kota yang dilengkapi dengan spot } \\
\text { kuliner }\end{array}$ \\
\hline $\mathbf{9}$ & $\begin{array}{l}\text { Stadion Mandala } \\
\text { Krida }\end{array}$ & Kecamatan Umbulharjo & \begin{tabular}{l} 
Stadion olahraga \\
\hline
\end{tabular}
\end{tabular}

Sumber: analisis peneliti, 2019

\section{HASIL DAN PEMBAHASAN \\ Profil responden}

Dari sembilan taman yang menjadi obyek dalam studi ini, masing-masing memiliki jumlah responden yang berbeda-beda. Kisarannya adalah berjumlah antara 27 orang partisipan sampai dengan 38 orang partisipan sebagaimana dilihat dalam gambar 2 berikut ini. Dari keseluruhan responden, $59.18 \%$ berjenis kelamin wanita. 


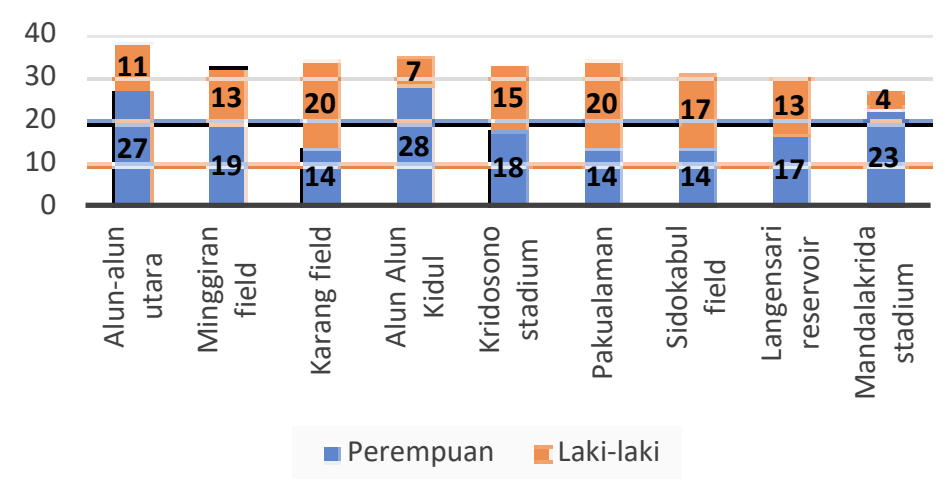

Gambar 2. Jumlah responden di setiap taman

Sumber: analisis peneliti, 2020

Dilihat dari komposisi usia, sebanyak 52.72\% dari jumlah total responden berusia 21-39 tahun, sebanyak $24.15 \%$ berusia $18-20$ tahun, sebanyak $20.41 \%$ berusia $40-59$ tahun, dan sisanya sebanyak $2.72 \%$ berusia 60 tahun ke atas. Sedangkan berdasarkan status pekerjaannya, $40 \%$ responden merupakan pelajar, sedangkan $21.09 \%$ merupakan karyawan, $18.37 \%$ merupakan wiraswasta / pengusaha, sedangkan sisanya berstatus Pegawai Negeri Sipil / Militer dan lain-lain.

Berdasarkan hasil pengumpulan kuisioner, dari dua ratus sembilan puluh empat (294) pengunjung taman diketahui bahwa taman dikunjungi oleh responden sebagai tempat untuk bersantai dan beristirahat oleh seratus dua puluh tiga (123) orang pengunjung taman, dan sebagai tempat untuk berolahraga oleh seratus dua puluh satu (121) orang pengunjung taman. Sedangkan sisanya memanfaatkan taman sebagai tempat bermain dan tujuan lainnya seperti menikmati kuliner yang ada di area tersebut. Berdasarkan pengamatan dari peneliti, olahraga yang banyak dilakukan di taman-taman tersebut adalah jalan sehat, jogging atau berlari. Hasil asesmen yang menunjukkan bahwa mayoritas taman digunakan sebagai tempat untuk duduk-duduk bersantai atau berolahraga ini menggambarkan bahwa taman selain memiliki fungsi sebagai penyeimbang lingkungan, juga mengakomodir kebutuhan ruang dari masyarakat untuk berolahraga atau melakukan aktivitas rekreasional lainnya. Hasil ini juga menguatkan argumen bahwa taman berkaitan erat dengan aktivitas fisik. Sebagai salah satu bentuk ruang terbuka hijau, keberadaan taman rekreasional menjadi salah satu ruang public yang penting untuk diperhatikan.

Taman merupakan salah satu ruang yang memiliki fungsi ekologikal untuk memelihara keseimbangan lingkungan seperti sebagai area tangkapan air, menurunkan kadar $\mathrm{CO} 2$ dan polusi udara lainnya, serta berkontribusi pada penurunan temperatur dengan keberadaan vegetasi di area tersebut. Selain itu taman merupakan tempat dimana masyarakat dapat bersosialisasi dan melakukan aktivitas rekreasional. Dalam hal ini taman memenuhi fungsi sosial-budaya. Ditilik lebih lanjut lagi, taman memiliki fungsi estetika yang memberikan keindahan suatu wilayah, termasuk sebagai penyeimbang antara kawasan terbangun (built-environment) dan kawasan tidak terbangun (non built-environment) di suatu kota.

Pemanfaatan taman sangat tergantung pada jenis taman dan fasilitas yang tersedia di taman tersebut. Seperti halnya pada sembilan unit taman yang menjadi obyek pada studi ini, dilengkapi dengan berbagai fasilitas yang tidak semuanya sama. Pada beberapa taman tersedia fasilitas bermain bagi anak (playground), atau spot kuliner, atau fasilitas olahraga yang nyaman yang menarik minat pengunjung untuk berkunjung ke taman dan memanfaatkan fasilitas yang tersedia di tempat itu. Atau ketersediaan tempat duduk taman yang memungkinkan pengunjung taman untuk sekedar duduk-duduk menikmati suasana taman di pagi atau sore hari. Contoh lain, di embung langensari dimana para pengunjungnya dimungkinkan untuk melakukan aktivitas memancing.

Dalam mengunjungi taman, para pengguna taman melaporkan frekuensi kunjungan ke taman yang bermacam-macam, mulai dari dua kali dalam satu minggu sampai kurang dari satu kali dalam satu bulan sebagaimana ditunjukkan pada gambar 3 dibawah ini.

\section{5| Taman dan Peranannya terhadap Aktivitas Berjalan Kaki Di Kota Yogyakarta}




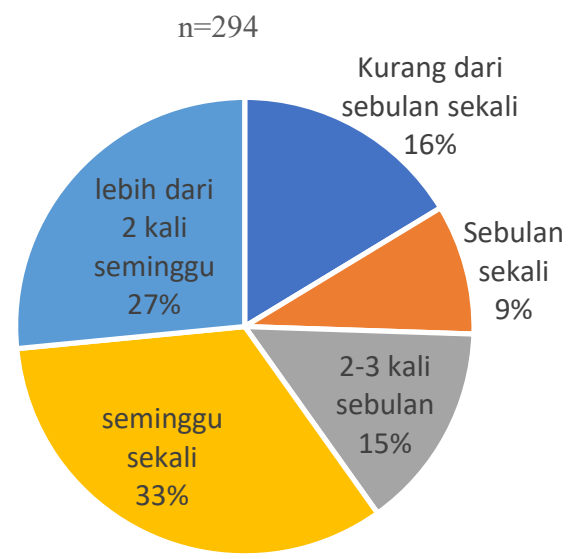

Gambar 3. Intensitas kunjungan ke taman

Sumber: analisis peneliti, 2020

Terkait dengan preferensi untuk berjalan kaki menuju taman, hanya $14.6 \%$ responden memilih untuk berjalan kaki sebagai preferensi moda transportasi yang dipilihnya untuk pergi ke taman. Sedangkan $75.9 \%$ pengunjung taman melaporkan tidak memilih moda transportasi berjalan kaki melainkan menggunakan kendaraan pribadi, bus umum, transportasi umum online, sepeda atau alat transportasi lainnya seperti yang ditunjukkan pada gambar 4 berikut ini.

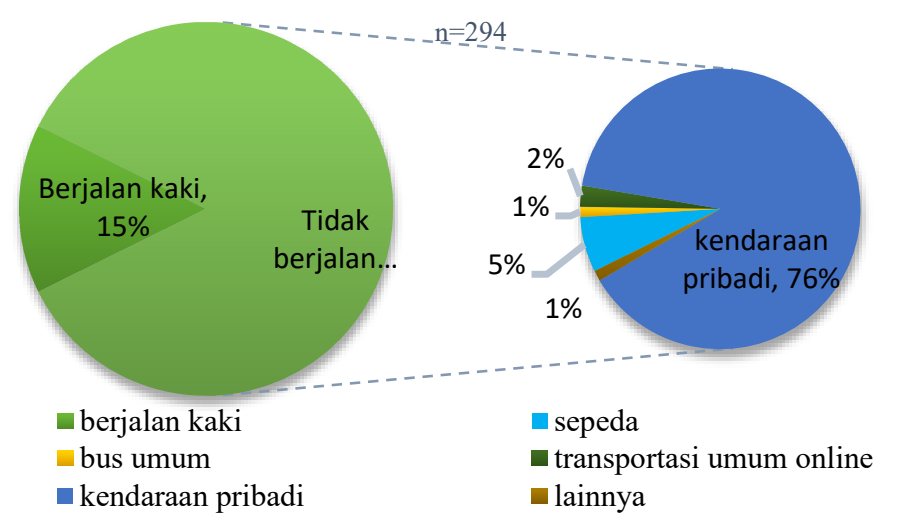

Gambar 4. Moda transportasi menuju taman

Sumber: analisis peneliti, 2020

Responden yang memilih untuk berjalan kaki ke taman teridentifikasi paling banyak memilih jarak yang dekat sebagai alasan mengapa mereka memutuskan untuk pergi ke taman dengan moda transportasi berjalan kaki. Sedangkan sisanya memilih berjalan kaki ke taman sebagai aktivitas olahraga mereka. Pada responden yang memilih untuk tidak berjalan kaki sebagai moda transportasi menuju ke taman, jarak tempuh juga menjadi alasan yang paling banyak dipilih. Sedangkan alasan lainnya adalah karena keterbatasan waktu yang dimiliki, sehingga mereka tidak memilih untuk berjalan kaki menuju ke taman seperti yang diperlihatkan pada gambar 5 dan 6 dibawah ini. 


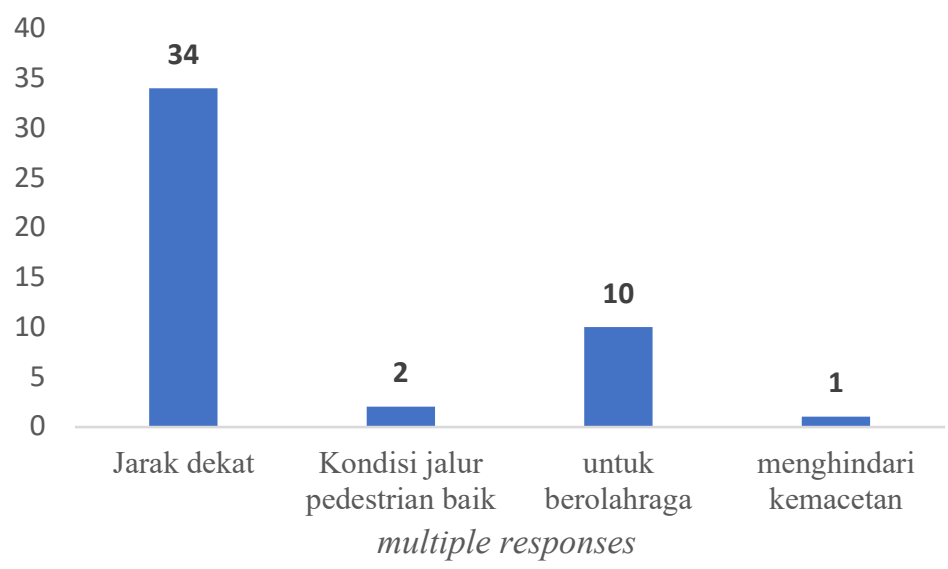

Gambar 5. Alasan preferensi berjalan kaki

Sumber: analisis peneliti, 2020

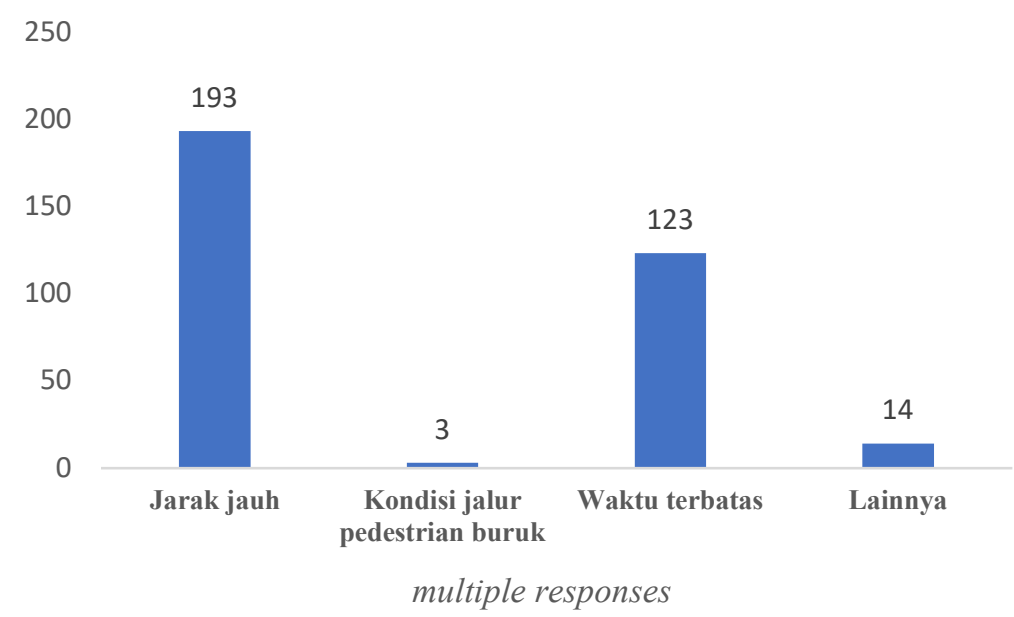

Gambar 6. Alasan preferensi tidak berjalan kaki

Sumber: analisis peneliti, 2020

Memperkuat hasil tersebut, apabila dilihat dari jarak yang ditempuh untuk menuju ke taman, 65.6\% partisipan melaporkan bahwa mereka menempuh jarak lebih dari 800 meter untuk menuju ke taman tersebut. Durasi yang ditempuh oleh $48.3 \%$ untuk menuju ke taman adalah antara 10-30 menit. Sedangkan sekitar $40.8 \%$ menempuh kurang dari 10 menit untuk pergi ke taman.

Sebagaimana disebutkan dalam lampiran Peraturan Menteri Pekerjaan Umum Nomor 03/PRT/2014, rata-rata jarak tempuh orang mau berjalan kaki di Indonesia yang memiliki karakteristik iklim yang panas adalah kurang lebih 400 meter, namun hal tersebut masih tergantung pada faktor lainnya misalnya aktivitas yang membawa barang seperti berbelanja, rata-rata orang hanya ingin berjalan tidak lebih dari 300 meter. Hal ini senada dengan laporan dari sebagian besar responden yang menyebutkan bahwa mereka menempuh jarak lebih dari 800 meter untuk mencapai taman tersebut, sehingga preferensi untuk berjalan kaki menuju ke taman sangat rendah. Banyaknya pengunjung yang menempuh jarak lebih dari 800 meter dapat disebabkan oleh karakteristik dari taman yang menjadi obyek dalam penelitian. Kapasitas taman yang besar sehingga bisa menampung banyak pengunjung, dan lokasinya yang berada ditepi jalan yang mudah diakses oleh masyarakat, serta tersedianya bermacam-macam fasilitas pendukung taman menjadikan taman ini dikunjungi oleh banyak pengunjung yang tidak hanya masyarakat yang berada di dalam kecamatan yang sama dengan taman tersebut, tetapi juga dari kecamatan lain, atau bahkan kabupaten lain seperti sleman atau bantul. Menurut Sugiyama,

\section{7| Taman dan Peranannya terhadap Aktivitas Berjalan Kaki Di Kota Yogyakarta}


T., Francis, et Al., (2010). Keberadaan sebuah taman yang memiliki ukuran besar pada umumnya akan menawarkan lebih banyak aktivitas yang bervariasi.

Hasil dari studi ini menunjukkan bahwa meskipun responden menyatakan mereka memanfaatkan taman sebagai tempat untuk berolahraga, melakukan aktivitas fisik atau aktivitas rekreasional lainnya, namun ternyata aktivitas tersebut dimulai setelah mereka tiba di tempat tersebut. Sedangkan untuk menuju ke tempat tersebut, hanya sedikit responden yang memiliki preferensi untuk berjalan kaki menuju ke taman.

Dari hasil analisis asosiatif dalam studi ini ditunjukkan bahwa jarak dan durasi tempuh menuju ke taman secara signifikan berkorelasi negatif pada preferensi berjalan kaki. Jarak tempuh berkorelasi dengan preferensi berjalan kaki dengan koefisien korelasi sebesar -0.536. Sedangkan waktu tempuh memiliki keeratan yang lemah, yaitu dengan koefisien korelasi sekitar -0.245 . Selain berpengaruh terhadap moda transportasi yang dipilih, jarak tempuh ke taman dan durasi waktu tempuh juga memiliki korelasi negatif yang signifikan terhadap intensitas kunjungan ke taman.

Jarak menjadi salah satu bahan pertimbangan bagi responden dalam memutuskan preferensi moda transportasi yang digunakan untuk menju ke taman. Semakin jauh jarak yang ditempuh, maka semakin kecil preferensinya untuk memilih moda transportasi berjalan kaki. Sebaliknya, responden akan memilih berjalan kaki apabila jarak tempuh menuju ke taman tidak jauh. Hal ini berarti semakin rendah jarak dan durasi tempuh maka semakin tinggi frekuensi kunjungan ke taman. Jarak dan durasi tempuh menuju taman ternyata juga berpengaruh pada intensitas atau frekuensi kunjungan ke taman. Semakin jauh jarak dan semakin lama durasi yang ditempuh maka frekuensi kunjungan ke taman akan semakin rendah. Sebaliknya masyarakat yang memiliki jarak dan durasi tempuh yang rendah, memiliki frekuensi kunjungan ke taman yang lebih tinggi.

Pada aktivitas berjalan kaki secara umum, Menurut ITDP (2019), ada beberapa elemen yang dapat menciptakan pengalaman berjalan kaki menjadi menyenangkan sehingga akan membuat orang mampu berjalan lebih lama atau menempuh jarak yang lebih jauh. Elemen-elemen tersebut antara lain ketersediaan peneduh baik alami maupun buatan, street furniture seperti kursi atau tempat sampah, tanaman atau vegetasi, visualisasi sisi muka bangunan dan blok-blok kecil. Ketersediaan peneduh yang dapat melindungi dari panas matahari dan street furniture seperti bangku dan tempat sampah akan dapat menambah kenyamanan dari pejalan kaki. Vegetasi dan tanaman hijau, selain berfungsi sebagai peneduh juga dapat memberikan nilai estetik dan keindahan di sepanjang jalur. Sedangkan keberadaan blok-blok kecil akan lebih menguntungkan bagi pejalan kaki, karena blok-blok kecil cenderung memiliki ruas jalan yang lebih pendek sebelum sampai di persimpangan jalan dibandingkan blok-blok besar. Pada umumnya blok kecil memiliki lebih banyak jalan tembus atau jalan alternatif menuju ke suatu tempat, sehingga pejalan kaki dapat memilih lebih banyak alternatif jalan untuk menuju ke tempat yang dituju.

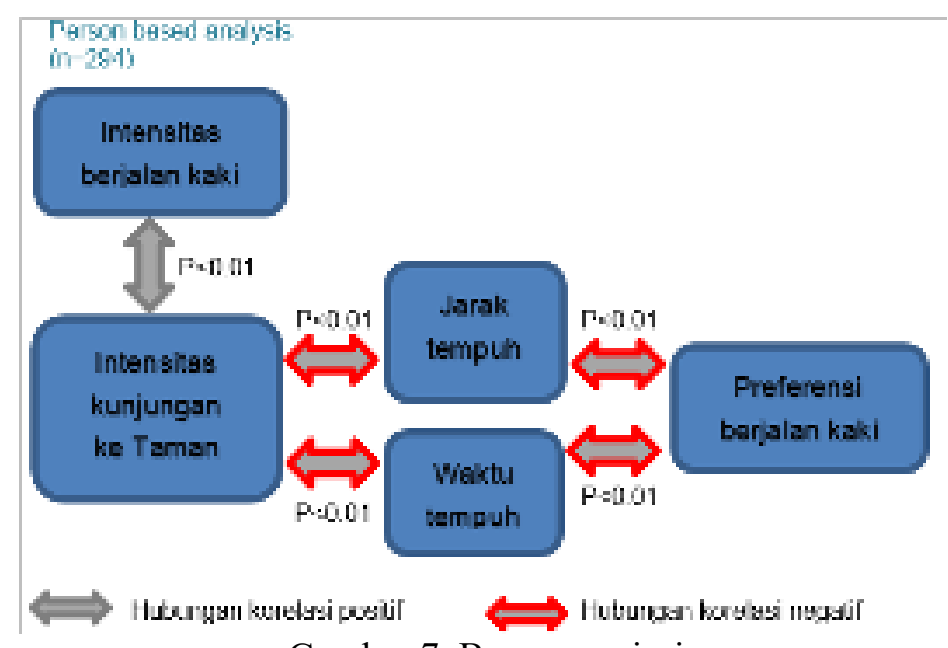

Gambar 7. Bagan asosiasi

Sumber: Analisis peneliti, 2020

Lebih lanjut, hasil analisis menunjukkan bahwa intensitas kunjungan ke taman memiliki korelasi yang signifikan dengan intensitas berjalan kaki $(\mathrm{p}<0.01)$ meskipun dengan level keeratan yang rendah (coef. 0.200). Tingginya intensitas kunjungan ke taman berkaitan dengan tingginya intensitas berjalan kaki. Intensitas berjalan kaki dalam hal ini menunjukkan frekuensi responden dalam melakukan aktivitas berjalan kaki. Dalam asesmen ini, $46.6 \%$ pengunjung taman mengaku dalam kesehariannya, mereka 
berjalan kaki setidaknya satu minggu sekali. Dan 37\% berjalan kaki lebih dari 5 kali seminggu. Mayoritas aktivitas berjalan kaki ditujukan sebagai aktivitas olahraga atau rekreasional bukan sebagai fungsi transportasi. Hasil studi ini selaras dengan hasil penelitian dari Rahman Muhammad Tauhidur and Nahiduzzaman Kh.Md, 2019, dimana dalam penelitian yang dilakukan di Arab Saudi tersebut hampir $65 \%$ responden menyatakan bahwa mereka melakukan aktivitas berjalan kaki sebagai aktivitas rekreasional atau berolahraga.

\section{DAFTAR PUSTAKA}

Adriana A. Zuniga-Teran, Barron J. Orr, Randy H. Gimblett, Nader V. Chalfoun, Stuart E. Marsh, David P. Guertin, Scott B. Going, 2017, Designing healthy communities: Testing the walkability model,Frontiers of Architectural Research,Volume 6, Issue 1, Pages 63-73,ISSN 2095-2635, https://doi.org/10.1016/j.foar.2016.11.005.

Badan Pusat Statistik, 2016, Kota Yogyakarta dalam angka 2015

Badan Pusat Statistik, 2020, Kota Yogyakarta dalam angka 2019

Bahrainy, et Al.. (2015). The Impact of Built Environment on Walkability, Case Study: North-West of Shiraz. Ar-manshahr Architecture \& Urban Development, 8(14)

Cambra, P. (2012). Pedestrian Accessibility and Attractiveness Indicators for Walkability Assessment. Engineering and Architecture, 1-10.https://fenix.tecnico.ulisboa.pt/downloadFile/ 2589873355564/ Dissertacao.pdf

Çay, R. D. (2015). Recreation and Urban Park Management. http://www.researchgate.net/ publication/300571449,

Dills, J. E., Rutt, C. D., \& Mumford, K. G. (2012). Objectively Measuring Route-To-Park Walkability in Atlanta, Georgia. Environment andBehavior, 44(6),841-860 https://doi.org/10.1177/ 0013916511404409

Dokumen Rencana Pembangunan Jangka Menengah Daerah Kota Yogyakarta 2017-2022, Kota Yogyakarta

Duncan, D. T., Méline, J., Kestens, Y., Day, K., Elbel, B., Trasande, L., \& Chaix, B. (2016). Walk score, transportation mode choice, and walking among french adults: A GPS, accelerometer, and mobility survey study. International Journal of Environmental Research and Public Health, 13(6),1-14. https://doi.org/10.3390/ijerph13060611

ITDP, 2019, Panduan desain fasilitas pejalan kaki: DKI Jakarta 2017-2022 (versi 2.0)

Kementerian Pekerjaan Umum, 2014, Peraturan Menteri Pekerjaan Umum Nomor 03/PRT/2014 tentang Pedoman Perencanaan, Penyediaan, Dan Pemanfaatan Prasarana Dan Sarana Jaringan Pejalan Kaki Di Kawasan Perkotaan

National Recreation and Park Association. (2015). Active Transportation and Parks and Recreation

Nasution, N., Widiyastuti, D., \& Purwohandoyo, J. (2018). Analisis Penilaian Fasilitas Pedestrian Di Kawasan Perkotaan (Kasus: Jalan Malioboro - Jalan Margo Mulyo, Yogyakarta). Jurnal Bumi Indonesia, 5(2). http://lib.geo.ugm.ac.id/ojs/index.php/jbi/article/view/715

Rahman, M. T., \& Nahiduzzaman, K. M. (2019). Examining the walking accessibility, willingness, and travel conditions of residents in saudi cities. International Journal of Environmental Research and Public Health, 16(4). https://doi.org/10.3390/ijerph16040545

Reisi, M., Nadoushan, M. A., \& Aye, L. (2019). Local walkability index: Assessing built environment influence on walking. In Bulletin of Geography. Socio-economic Series (Vol. 46, Issue 46, pp. 7-21). Sciendo. https://doi.org/10.2478/bog-2019-0031

Saelens, B.E. Sallis, J.F. and Frank, L.D. (2003). Environmental correlates of walking and cycling: findings from the transportation, urban design, and planning literatures. Annals of behavioral medicine, 25(2): 80-91. DOI: https://doi.org/10.1207/S15324796ABM2502_03

Song, Y., Preston, J., \& Ogilvie, D. (2017). New walking and cycling infrastructure and modal shift in the UK: A quasi-experimental panel study. Transportation Research Part A: Policy and Practice, 95, 320-333. https://doi.org/10.1016/j.tra.2016.11.017

Sugiyama, T., Francis, et Al.. (2010). Associations between recreational walking and attractiveness, size, and proximity of neighborhood open spaces. American journal of public health, 100(9), 1752-1757. https://doi.org/10.2105/AJPH.2009.182006

\section{9| Taman dan Peranannya terhadap Aktivitas Berjalan Kaki Di Kota Yogyakarta}


Sugiyono, 2009. Metode Penelitian Bisnis (Pendekatan Kuantitatif, Kualitatif, dan R\&D). Bandung: Alfabeta

Sujarweni V. Wiratna, 2019, SPSS untuk penelitian, Pustaka Baru Press Yogyakarta

Tribby, et.Al. (2016). Assessing Built Environment Walkability using Activity-Space Summary Measures. Journal of Transport and Land Use. 9. 187-207. 10.5198/jtlu.2015.625..

Wibowo, A., \& Ritonga, M. (2018). Kebutuhan Pengembangan Standar Nasional Indonesia Fasilitas Taman Kota. Jurnal Standardisasi, 18(3), 161. https://doi.org/10.31153/js.v18i3.234 